\title{
The Influence of Humic Fertilizer on Soybean Yield and Economic Efficiency in Moldavian Plateau
}

\author{
Daniel Costel GALEŞ*, Gerard JITĂREANU
}

Department of Pedotechnics, University of Agricultural Sciences and Veterinary Medicine of Iasi, Mihail Sadoveanu Alley, no. 3, 700490 Iasi, România.

* corresponding author: galesdan@yahoo.com

Bulletin USAMV series Agriculture 72(1)/2015

Print ISSN 1843-5246; Electronic ISSN 1843-5386

DOI 10.15835/buasvmcn-agr: 10423

\begin{abstract}
This study aimed to quantify the influence of a humic fertilizer (Lignohumate) on the productivity elements, yield and economic efficiency on soybean. The tested humic fertilizer contains chelate micronutrients and is free of ballast, acting as incentive for growth and as anti-stress agent for plants. The experimental field was located at the

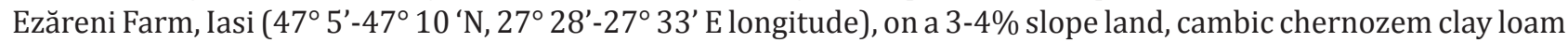
soil, with medium content of $\mathrm{N}$ and $\mathrm{P}_{2} \mathrm{O}$ and good content of $\mathrm{K}_{2} \mathrm{O}$. The $\mathrm{pH}$ is slightly acidic and the humus content is around 2.5-3.0\%. A treatment on seeds with a dose of $100 \mathrm{~g} / 10 \mathrm{~L}$ of water/t of seeds and three treatments on vegetation (2-3 leafs stage, before and after flowering) with a dose of $60 \mathrm{~g} / \mathrm{ha} / 300 \mathrm{~L}$ of water were applied. The results after three experimental years showed a positive influence of the Lignohumate treatments, the differences compared to the control (untreated) being statistically assured, both for the yield and the productivity elements. The economic efficiency of the fertilizer use was influenced by climatic conditions of the experimental years, in the normal years regarding the climatic conditions (2010 and 2011), there has been a profit and in 2012, considered to be extremely dry, the losses were reduced with $2.7 \%$ at the treated variant, compared to the untreated control.
\end{abstract}

Key words: lignohumate, humic fertilizer, soybean, yield, economic efficiency.

\section{INTRODUCTION}

Humic substances are defined as a general class of organic matter present in the natural environment. Almost all life in the soil is dependent on organic matter for nutrients and energy. People have long recognized the importance of organic matter for plant growth. Although organic matter in soils is very beneficial, Justus von Liebig, a famous German chemist, pointed out about 150 years ago that soils composed entirely of organic matter are naturally infertile Forth and Turk, 1972 cited by Topa. et al., (2013).

They are biogenic, heterogeneous, characterized by a color ranging from yellow to black and with high molecular weight Aiken et al. 1985 cited by Leenheer, (2002).
The humic substances form a specific group of substances produced as a result of decomposition of organic residues in soil by synthesis of products of decay (putrefaction of dead animal and plant tissues). Humic substances are produced by organic evolution of mineral materials, not only the simple degradation. These are quantified by organic carbon content which is increased 1.724 times. This coefficient is the ratio of the average humus weight and the mean carbon content of humus $100: 58 \% \mathrm{C}=1.724$, Borlan, et al. (1994).

Lignohumate (the tested humic fertilizer) contains chelated micronutrients with and without ballast acting as a driver of growth and plant antistress agent. It is produced by the oxidation / hydrolytic destruction of lignin-containing raw 


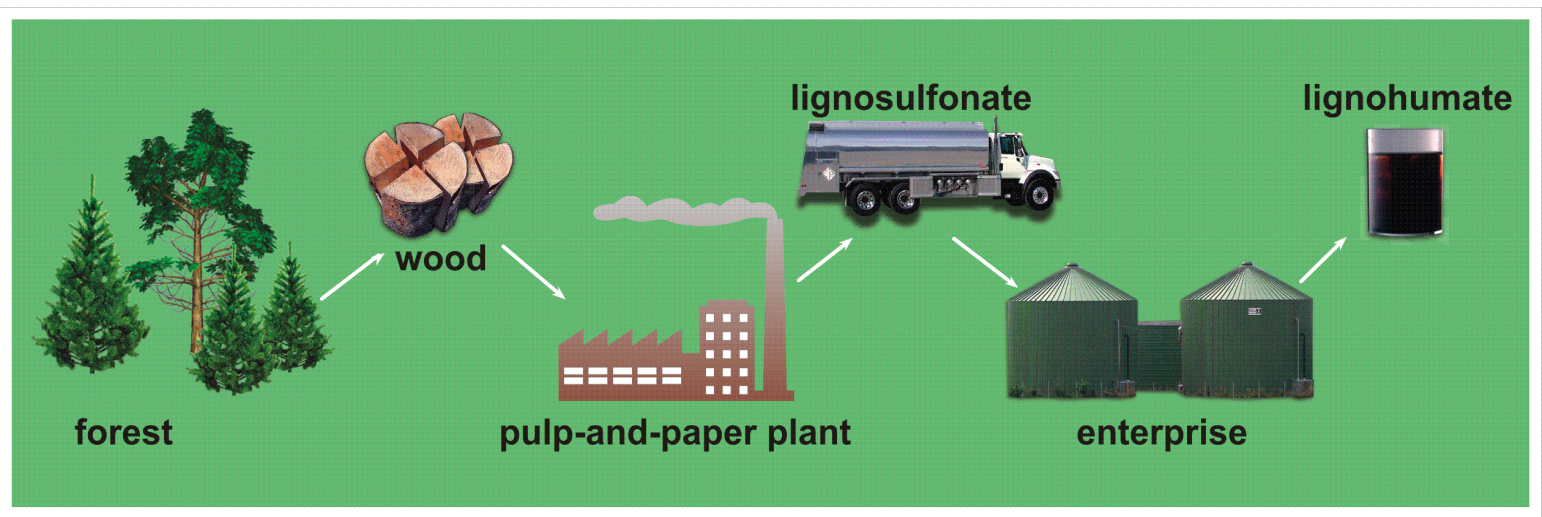

Fig. 1. Manufacturing scheme of Lignohumat (Oleg and Rodion, 2010)

material, the production scheme being shown in Fig. 1. Research has shown that the humates contain more than $60 \%$ organic matter (carbon equivalent), while the content of acid-soluble fraction (fulvic acids, polybasic organic acids and other organic substances) reaches $40 \%$.

The Lignohumate is made by the unique patented technology of accelerated humification of ligno-sulphonates. The transformation of lignosulphonates in humic products is conducted over 1.5-2 hours in an oxidizing atmosphere, the whole technological process being supervised by a special program Gladkov O., Rodion P., (2010).

The mineral components of Lignohumate include macro and micronutrients. Most of the Lignohumate weight, about $20 \%$, is represented by sodium and potassium, elements that depend on the hydroxide cations used in the technologic process of humate production. Among other fertilizers used in modern agriculture (e.g. biofertilizers based on rhizobacteria Stefan M., (2008)), the Lignohumate is a highly efficient and

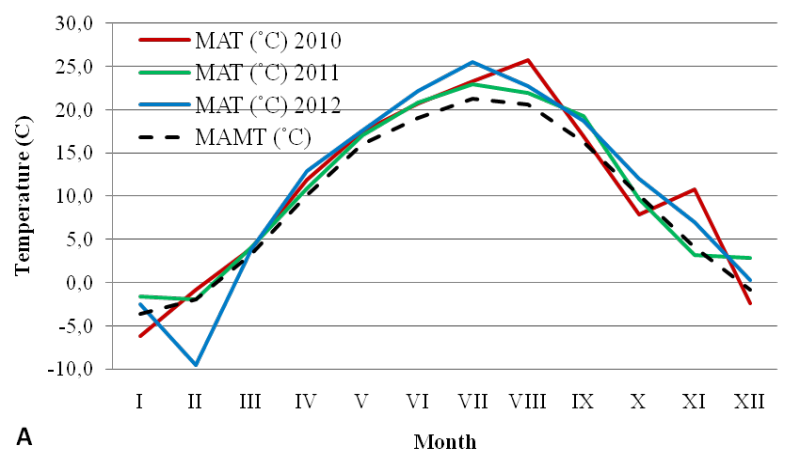

MAT - Multi-annual temperature

MAMT - Multi-annual mean temperature practically feasible humic fertilizer, with important growth stimulant properties.

The aim was to introduce in the soybean crop technology the Lignohumate humic fertilizer and to quantify the influence of its use on yield, productivity elements (HW and TGM) and the economic efficiency of its use in soybean crop.

\section{MATERIALS AND METHODS}

The experiment was located in the climatic conditions of the Moldavian Plateau (Romania) at the Ezăreni Farm, in the Iasi County with the coordinates $47^{\circ} 5^{\prime}-47^{\circ} 10^{\prime}$ ' N latitude and 27 $33^{\prime}$ $-27^{\circ} 28^{\prime}$ E longitude, on a cambic chernozem, clay loam, formed on loess deposits, with a medium to good fertility (medium supplied with $\mathrm{N}$ and $\mathrm{P}_{2} \mathrm{O}$ and well supplied with $\mathrm{K}_{2} \mathrm{O}$ ) with a slightly acidic $\mathrm{pH}$ and a humus content of about 2.5 to $3.0 \%$ and a slope of 3-4\%.

The climatic conditions that characterized the analyzed period of time are shown in figure 2 (A-temperature, B-rainfall).

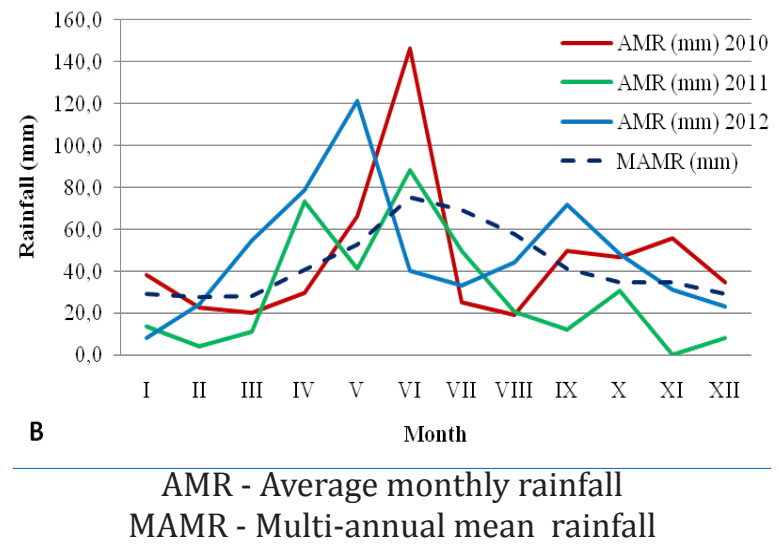

Fig. 2. Characterization of climatic factors for 2010-2012

(A - air temperature, B - rainfall) 


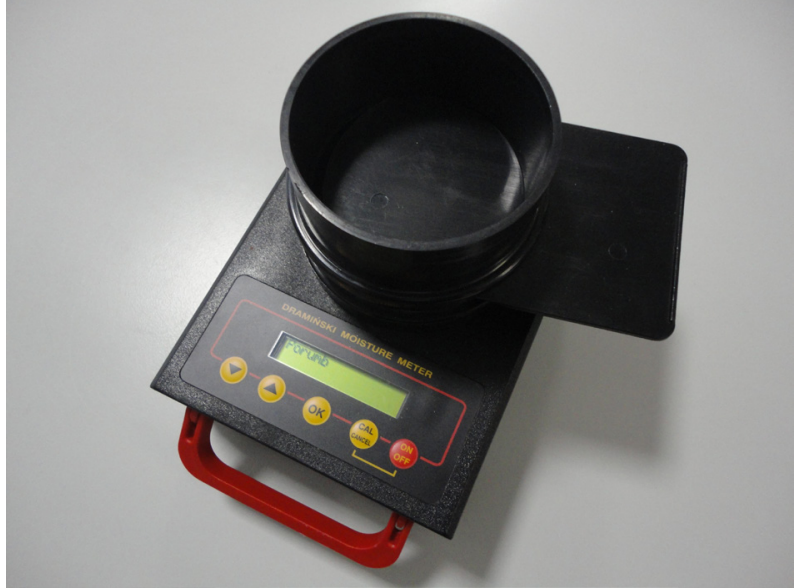

Fig. 3. Humidity measuring device for T1 seeds

Fertilization was made with $60 \mathrm{~kg} / \mathrm{ha} \mathrm{P}_{2} \mathrm{O}_{5}$ $+60 \mathrm{~kg} / \mathrm{ha} \mathrm{N}$, before the seedbed preparation, following mainly the classical technology for the soybean crop. The seedbed was prepared on the day of sowing, using the kompaktor cultivator and the sowing was done with SPC6 + U650. We used the Pioneer PR91M10 hybrid.

The sowing was carried out when the temperature in the soil has reached a minimum of 7-8 ${ }^{\circ} \mathrm{C}$, corresponding to 14 to $15{ }^{\circ} \mathrm{C}$ average daily temperature, using a dose of $90 \mathrm{~kg} / \mathrm{ha}$. The sowing was carried out in strips of three rows at $45 \mathrm{~cm}$, with $60 \mathrm{~cm}$ between them, and the depth was between 4 and $5 \mathrm{~cm}$.

Chemical weed control was achieved with a pre-emergent treatment with Dual Gold 960 EC herbicide $(1.0 \mathrm{~L} / \mathrm{ha})$, which controls some annual monocotyledonous weeds and some dicotyledonous weeds (Setaria sp., Echinochloa sp., Digitaria sp. , Amaranthus spp. Chenopodium sp. Hibiscus sp.) and Basagran was used postemergent ( $2 \mathrm{~L} / \mathrm{ha})$.

The humic fertilizer has been placed in the crop technology of soybean in a seed treatment with $100 \mathrm{~g}$ Lignohumate for 10 liters of water / $\mathrm{t}$ of seeds and three foliar applications in the 2-3 leaves stages, before and after flowering, using each time a dose of $60 \mathrm{~g} / \mathrm{ha} / 300$ liters of water per treatment.

A. Determination of seed moisture by the electrometric method was done according to SR 6124 1/1999 stipulations. To determine the seed moisture content using an electronic hygrometer T1 type from Winteck, with which the seeds moisture can be determined within the range of 5-36 \% Axinte M. et al., (2002)
(Fig. 3). This electronic hygrometer can be used to determine the moisture of corn, wheat, rye, barley, oats and rice grains, sunflower seeds, beans and soybean.

The principle of the method consists in determining the moisture content of seeds based on the correlation between the electrical conductivity of the seeds and their water content.

For meaningful results there were made five measurements, taking the average of these measurements as the final result, and the correction of the differences in moisture content was made using the relationship:

$P_{\text {STAS }}=P_{\text {weighed }} \times \frac{100-U \%_{\text {DETERMINED }}}{100-U \%_{\text {STAS }}}$,

where:

P - Yield (kg/ha)

U\% - Seeds moisture (\%)

\section{B. Determination of the hectolitic weight} (HW) (according to SR 6123-2/1999 stipulations).

It was determined using the hectoliter balance for establishing the seed mass which occupy a volume of 1 liter.

The final result is the arithmetic mean of two consecutive measurements, which don't include differences higher than $0.5 \mathrm{~kg} / \mathrm{hl}$. If there are differences higher than $0.5 \mathrm{~kg} / \mathrm{hl}$, the result will be the arithmetic mean of four determinations.

C. Thousand grains weight (TGW) was determined according to SR 6123/1999 stipulations.

TGW is an indicator that allows the assessment of seed size and indirectly characterize the production capacity of a variety or hybrid, whereas there is a strong correlation between TGW and yields.

Regarding the working procedure we take the appropriate amount of beans for about 5000 seeds, we remove the impurities, weight and count. The result expresses the arithmetic mean of two parallel determinations, among which there must not exist a difference higher than that allowed by STAS. For values less than 10 grams, the result is expressed with two decimal places, for values between 10 and 15 grams with one decimal place and the values over 15 grams are expressed as whole numbers. 
To determine the absolute mass of 1000 grains, there will be determined also their moisture, and for calculating the following relations are used:

$$
\begin{aligned}
& T G W_{\text {absolute }}=\frac{100-U \%}{100} T G W_{\text {relative }} \\
& T G W_{\text {relative }}=\frac{M}{n} 1000,
\end{aligned}
$$

where:

$\mathrm{M}$ - weight of seeds ( $\mathrm{g}$ );

$\mathrm{n}$ - number of seeds in the test sample;

U\% - seeds moisture (\%).

\section{Economic efficiency}

To determine the economic efficiency there were calculated: the average yield, total expenses, the production cost, the profit and the profit rate.

Average production - expresses the yield obtained (kg) per unit of production (ha) and is calculated using the formula:

$$
Q m=\frac{Q t}{S c},
$$

where:

Qm - the average yield per hectare (kg / ha);

$\mathrm{Qt}$ - total production $(\mathrm{kg})$;

Sc - cultivated area (ha).

Cost of production - reflects the production costs incumbent per unit of product and is calculated using the relationship:

$$
C p=\frac{C h t}{Q t}
$$

where:

Cp - cost of production (lei);

Cht - total expenses (lei)

$\mathrm{Qt}$ - total production (kg).

The profit - represents the compensation which an entrepreneur deserves and is calculated deducting from the total revenue all the components of production costs.

The rate of profit - indicator expressing the profit made for every 100 lei production costs. We determined it with the formula:

$R p=\frac{\operatorname{Pr}}{C h t} \times 100$

where:
Rp - rate of profit (\%);

Pr - profit (lei);

Cht - total expenses (lei)

\section{RESULTS AND DISCUTIONS \\ Elements of productivity}

Determination of the weight of a thousand grains (TGW)

The Lignohumate treatments positively influenced TGW in all three years of experience. Thus, we obtained significant differences between treated variant and control, and they ranged between $3.3 \mathrm{~g}$ in 2010 and $1.4 \mathrm{~g}$ in 2012. In 2011 we observed a moderate influence of Lignohumate treatments on the TGW, the difference compared to the control in which TGW was $172.7 \mathrm{~g}$, being of $2.9 \mathrm{~g}$ (Tab. 1).

Looking at the average values over the three years of the indicator TGW, we observe that Lignohumate treatments have contributed to an increased TGW for soybean in $V_{2}$ variant compared to the control $V_{1}$ where no treatments were applied. The variant treated with Lignohumate obtained an average TGW of $171.6 \mathrm{~g}$ while the control variant $\mathrm{V}_{1}$ obtained a TGW value of $169.1 \mathrm{~g}$ (Tab. 1). The difference of $2.5 \mathrm{~g}$ was statistically significant, and this aspect leads us to conclude that Lignohumate treatments have a direct influence on this indicator.

Determination of the hectolitric weight (HW)

The results showed no significant variation of this indicator after applying Lignohumate treatments. Statistical calculation showed that only in 2012 the value of the HW indicator in variant $\mathrm{V}_{2}$ treated with Lignohumate was below the value obtained from the control variant $V_{1}$ (Tab. 2).

The hectolitric mass was in 2010 of $74.3 \mathrm{~kg}$ in $\mathrm{V}_{1}$ and $74.6 \mathrm{~kg}$ in $\mathrm{V}_{2}$, in 2011 of $71.5 \mathrm{~kg}$ in $\mathrm{V}_{1}$ and $71.6 \mathrm{~kg}$ in $V_{2}$ and in 2012 of $68.2 \mathrm{~kg}$ in $V_{1}$ and 67.4 $\mathrm{kg}$ respectively in $\mathrm{V}_{2}$. Quite large variations from year to year of this indicator are due solely to the climatic conditions. The year 2012 is considered less favorable for the soybean crop and it gave the smallest values of the HW indicator.

The analysis of average values for the three years of experiment showed that the HW was not influenced by the Lignohumate treatments. Between the treated variant $V_{2}$ and the control $\mathrm{V}_{1}$, the difference, statistically assured, is of $0.1 \mathrm{~kg}$ (Tab. 2).

Yields 
In the three years of experience, the soybean crop yields varied widely from year to year, but these changes were not a consequence of the studied factor, being due to climatic conditions prevailing in those years. The climatic conditions of 2010 have contributed to the highest yields compared to the years 2011 and 2012 (Fig. 4). The highest production increase was achieved in 2010, when for the treated variant the production was $4536 \mathrm{~kg} / \mathrm{ha}$ versus $4402 \mathrm{~kg} / \mathrm{ha}$ in control (Tab. 3).

The statistical analysis of the obtained data reveals that only in 2011 the yield difference between the variant treated with Lignohumate

Tab. 1. The influence of the Lignohumat on TGW (Thousand Grain Weight) in soybean crop (20102012)

\begin{tabular}{|c|c|c|c|c|c|}
\hline \multirow[b]{2}{*}{ Year } & \multirow[b]{2}{*}{ Variant } & \multicolumn{2}{|c|}{ TGW } & \multirow[b]{2}{*}{$\begin{array}{l}\text { Difference } \\
\text { (g) }\end{array}$} & \multirow[b]{2}{*}{ Significance } \\
\hline & & $\mathrm{g}$ & $\begin{array}{c}\% \text { compared } \\
\text { to control }\end{array}$ & & \\
\hline \multirow{3}{*}{2010} & $\mathrm{~V}_{1}$ - Control (untreated) & 171.7 & 100.00 & 0.0 & Control \\
\hline & $\mathrm{V}_{2}$ - Lignohumate $^{*}$ & 175.0 & 101.92 & 3.3 & $\mathrm{xx}$ \\
\hline & LSD $5 \%=1.2 \mathrm{~g}$ & \multicolumn{2}{|c|}{ LSD $1 \%=2.9 \mathrm{~g}$} & \multicolumn{2}{|c|}{$\operatorname{LSD} 0.1 \%=9.1 \mathrm{~g}$} \\
\hline \multirow{3}{*}{2011} & $\mathrm{~V}_{1}$ - Control (untreated) & 172.7 & 100.00 & 0.0 & Control \\
\hline & $\mathrm{V}_{2}$ - Lignohumate ${ }^{*}$ & 175.6 & 101.68 & 2.9 & $\mathrm{xx}$ \\
\hline & LSD $5 \%=1.2 \mathrm{~g}$ & \multicolumn{2}{|c|}{ LSD $1 \%=2.9 \mathrm{~g}$} & \multicolumn{2}{|c|}{ LSD $0.1 \%=9.1 \mathrm{~g}$} \\
\hline \multirow{3}{*}{2012} & $\mathrm{~V}_{1}$ - Control (untreated) & 163.0 & 100.00 & 0.0 & Control \\
\hline & $\mathrm{V}_{2}$ - Lignohumate ${ }^{*}$ & 164.4 & 100.86 & 1.4 & $\mathrm{xx}$ \\
\hline & LSD $5 \%=0.3 \mathrm{~g}$ & \multicolumn{2}{|c|}{ LSD $1 \%=0.7 \mathrm{~g}$} & \multicolumn{2}{|c|}{ LSD $0.1 \%=2.3 \mathrm{~g}$} \\
\hline \multirow{3}{*}{$\begin{array}{c}\text { Average } \\
2010- \\
2012\end{array}$} & $\mathrm{~V}_{1}$ - Control (untreated) & 169.1 & 100.00 & 0.0 & Control \\
\hline & $\mathrm{V}_{2}$ - Lignohumate ${ }^{*}$ & 171.6 & 101.48 & 2.5 & $\mathrm{xx}$ \\
\hline & $\mathrm{LSD} 5 \%=0.9 \mathrm{~g}$ & \multicolumn{2}{|r|}{$=2.1 \mathrm{~g}$} & \multicolumn{2}{|c|}{ LSD $0.1 \%=6.8 \mathrm{~g}$} \\
\hline
\end{tabular}

Tab. 2. The influence of the Lignohumat on HW (Hectolitric Weight) in soybean crop (2010-2012)

\begin{tabular}{|c|c|c|c|c|c|}
\hline \multirow[b]{2}{*}{ Year } & \multirow[b]{2}{*}{ Variant } & \multicolumn{2}{|c|}{$\mathrm{HW}$} & \multirow[b]{2}{*}{$\begin{array}{l}\text { Difference } \\
\quad(\mathrm{kg})\end{array}$} & \multirow[b]{2}{*}{ Significance } \\
\hline & & $\mathrm{kg}$ & $\begin{array}{c}\% \text { compared } \\
\text { to control }\end{array}$ & & \\
\hline \multirow{3}{*}{2010} & $\mathrm{~V}_{1}$ - Control (untreated) & 74.3 & 100.00 & 0.0 & Control \\
\hline & $\mathrm{V}_{2}-$ Lignohumate $^{*}$ & 74.6 & 100.40 & 0.3 & \\
\hline & LSD $5 \%=0.7 \mathrm{~kg}$ & \multicolumn{2}{|c|}{ LSD $1 \%=1.7 \mathrm{~kg}$} & \multicolumn{2}{|c|}{ LSD $0.1 \%=5.5 \mathrm{~kg}$} \\
\hline \multirow{3}{*}{2011} & $\mathrm{~V}_{1}$ - Control (untreated) & 71.5 & 100.00 & 0.0 & Control \\
\hline & $\mathrm{V}_{2}-$ Lignohumate $^{*}$ & 71.6 & 100.14 & 0.1 & \\
\hline & $\operatorname{LSD} 5 \%=0.4 \mathrm{~kg}$ & \multicolumn{2}{|c|}{$\operatorname{LSD} 1 \%=0.8 \mathrm{~kg}$} & \multicolumn{2}{|c|}{ LSD $0.1 \%=2.7 \mathrm{~kg}$} \\
\hline \multirow{3}{*}{2012} & $\mathrm{~V}_{1}$ - Control (untreated) & 68.2 & 100.00 & 0.0 & Control \\
\hline & $\mathrm{V}_{2}$ - Lignohumate ${ }^{*}$ & 67.4 & 98.83 & -0.8 & \\
\hline & LSD $5 \%=2.1 \mathrm{~kg}$ & \multicolumn{2}{|c|}{$\operatorname{LSD} 1 \%=4.9 \mathrm{~kg}$} & \multicolumn{2}{|c|}{ LSD $0.1 \%=15.5 \mathrm{~kg}$} \\
\hline \multirow{3}{*}{$\begin{array}{c}\text { Average } \\
2010- \\
2012\end{array}$} & $\mathrm{~V}_{1}$ - Control (untreated) & 71.3 & 100.00 & 0.0 & Control \\
\hline & $\mathrm{V}_{2}$ - Lignohumate ${ }^{*}$ & 71.2 & 99.86 & -0.1 & \\
\hline & LSD $5 \%=0.5 \mathrm{~kg}$ & \multicolumn{2}{|c|}{ LSD $1 \%=1.1 \mathrm{~kg}$} & \multicolumn{2}{|c|}{ LSD $0.1 \%=3.5 \mathrm{~kg}$} \\
\hline
\end{tabular}


and the control variant is not statistically assured, being of $54 \mathrm{~kg} /$ ha grain, i.e. $1.54 \%$ (Tab. 3).

This is attributed to the climatic conditions that have not made a significant contribution to the capitalization of Lignohumate treatments. In 2012 we obtained the lowest yields compared to the years 2010 and 2011, and this is solely due to climatic conditions, specifically to the lack of rainfall in the second part of the vegetation season. Despite this, Lignohumate treatments positively influenced the soybean production. Thus, between the Lignohumate treated variant $\mathrm{V}_{2}$ and the control variant $V_{1}$ we achieved a statistically significant difference, the production increase being of +78 $\mathrm{kg} / \mathrm{ha}$ (Tab. 3).

The average production values for the three years of experience indicate some differences between the Lignohumate treated variant $V_{2}$ and the control variant $V_{1}$ which are statistically assured. The mean production growth in the Lignohumate treated variant was $89 \mathrm{~kg} / \mathrm{ha}$

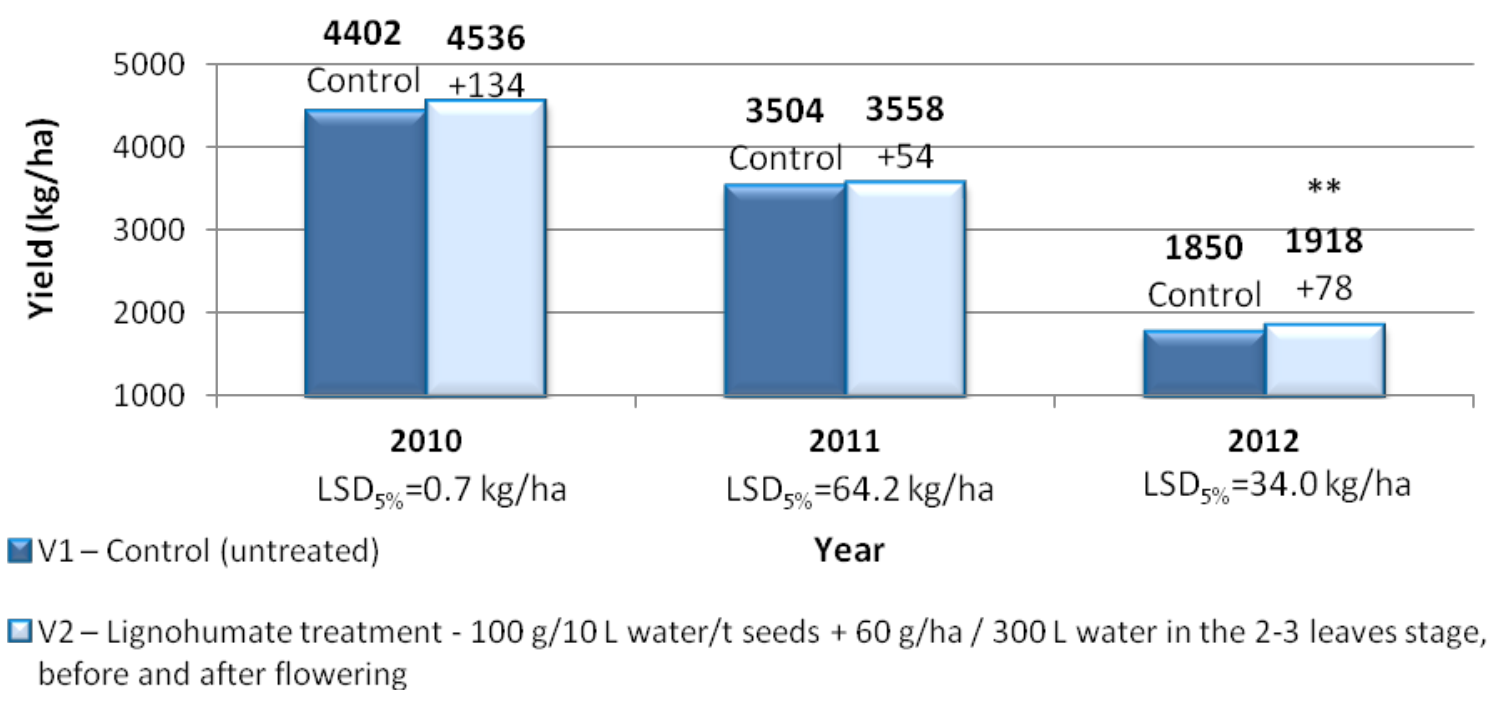

Fig. 4. The influence of the Lignohumat on yield in soybean crop (2010-2012)

Tab. 3. The influence of the Lignohumat on yield in soybean crop (2010-2012)

\begin{tabular}{|c|c|c|c|c|c|}
\hline \multirow[b]{2}{*}{ Year } & \multirow[b]{2}{*}{ Variant } & \multicolumn{2}{|c|}{ Yield } & \multirow[b]{2}{*}{$\begin{array}{l}\text { Difference }(\mathrm{kg} / \\
\text { ha) }\end{array}$} & \multirow[b]{2}{*}{ Significance } \\
\hline & & $\mathrm{kg} / \mathrm{ha}$ & $\begin{array}{c}\% \text { compared to } \\
\text { control }\end{array}$ & & \\
\hline \multirow{3}{*}{2010} & $\mathrm{~V}_{1}$ - Control (untreated) & 4402 & 100,00 & 0 & Control \\
\hline & $\mathrm{V}_{2}-$ Lignohumate $^{*}$ & 4536 & 103,04 & 134 & $\mathrm{xx}$ \\
\hline & LSD $5 \%=71.1 \mathrm{~kg} / \mathrm{ha}$ & \multicolumn{2}{|c|}{ LSD $1 \%=111.5 \mathrm{~kg} / \mathrm{ha}$} & \multicolumn{2}{|c|}{ LSD $0.1 \%=189.8 \mathrm{~kg} / \mathrm{ha}$} \\
\hline \multirow{3}{*}{2011} & $\mathrm{~V}_{1}$ - Control (untreated) & 3504 & 100.00 & 0 & Control \\
\hline & $\mathrm{V}_{2}-$ Lignohumate $^{*}$ & 3558 & 101.54 & 54 & \\
\hline & LSD $5 \%=64.2 \mathrm{~kg} / \mathrm{ha}$ & \multicolumn{2}{|c|}{ LSD $1 \%=100.7 \mathrm{~kg} / \mathrm{ha}$} & \multicolumn{2}{|c|}{ LSD $0.1 \%=171.4 \mathrm{~kg} / \mathrm{ha}$} \\
\hline \multirow{3}{*}{2012} & $\mathrm{~V}_{1}$ - Control (untreated) & 1766 & 100.00 & 0 & Control \\
\hline & $\mathrm{V}_{2}-$ Lignohumate $^{*}$ & 1844 & 104.42 & 78 & $\mathrm{xx}$ \\
\hline & LSD $5 \%=34.0 \mathrm{~kg} / \mathrm{ha}$ & \multicolumn{2}{|c|}{ LSD $1 \%=53.3 \mathrm{~kg} / \mathrm{ha}$} & \multicolumn{2}{|c|}{ LSD $0.1 \%=90.7 \mathrm{~kg} / \mathrm{ha}$} \\
\hline \multirow{3}{*}{$\begin{array}{c}\text { Average } \\
2010- \\
2012 \\
\end{array}$} & $\mathrm{~V}_{1}$ - Control (untreated) & 3224 & 100.00 & 0 & Control \\
\hline & $\mathrm{V}_{2}-$ Lignohumate $^{*}$ & 3313 & 102.76 & 89 & $\mathrm{xx}$ \\
\hline & LSD $5 \%=56.5 \mathrm{~kg} / \mathrm{ha}$ & LSD 1 & $=88.5 \mathrm{~kg} / \mathrm{ha}$ & LSD $0.1 \%=$ & $0.7 \mathrm{~kg} / \mathrm{ha}$ \\
\hline
\end{tabular}


compared to the control variant in which the average production was of $3224 \mathrm{~kg} / \mathrm{ha}$ (Tab. 3).

Economic efficiency analysis

The purpose of an experience is not always to obtain the highest yields because in many cases they are not the most economically profitable, so the main focus of the experience is to get the highest and economically efficient yields.

Tab. 4 presents a guide to estimating and planning of expenditures, by which total costs were determined for each analyzed crop. Preparation of this guide was based on the technological sheets made separately for each crop.

To determine the economic efficiency, some calculations were performed after which it was established that the necessary expenses, starting from the beginning up to production capitalization, varies each year between 4029-4323 lei/ha (Tab. 4). These costs do not include the foliar fertilizer treatments tested, which are made differently for each variant.

In calculating the data in Tab. 5 we used a price of $150.5 \mathrm{lei} / \mathrm{kg}$ Lignohumate. The price for the technology that included the humic fertilizer was increased compared to the classical technology cost of 42.14 lei/ha. The selling price was 1.4 lei for $\mathrm{kg} /$ grain in 2010, 1.7 lei for kg/grain in 2011 and 1.9 lei for $\mathrm{kg}$ /grain in 2012.

The profit rate for each experimental variant is shown in Fig. 5 and in Tab. 5 this aspect is detailed.

The Lignohumate treatments have helped to increase the profit rate in all three experimental years, by $3.0 \%$ in 2010 , by $0.6 \%$ in 2011 and by $2.7 \%$ in 2012 (Tab. 5).

Previous researches Galeș D.C., Jităreanu G., (2014) and the data from literature Eyheraguibel B., (2008), Eladia M. Pena-Mendez, (2005) showed that the use of humic substances in agriculture lead to an improvement of some plant morphophysiological indicators and indirectly, to an increased yield. In most of the cases, along with the yield increase, there is an economically efficiency of the crop. Oleg Gladkov, Rodion Poloskin, (2010) showed that the plants treated with Lignohumate had a maximum of seed productivity and also a maximum of secondary production weight (straws), but the average plant height was lower than the one of plants cultivated in soil treated with simple urea, without Lignohumate. Also, it was noticed a positive tendency of plant stem

Tab. 4. Planning and estimating guide of costs soybean crop

\begin{tabular}{cccc}
\hline Specification & 2010 & 2011 & 2012 \\
\cline { 2 - 4 } & (lei/ha) & (lei/ha) & (lei/ha) \\
\hline 1. Seeds & 572 & 577 & 594 \\
\hline 2. Fertilizers & 1383 & 1393 & 1533 \\
\hline 3. Herbicides & 323 & 338 & 365 \\
\hline 4. Fuels & 417 & 432 & 464 \\
\hline 5. Repairs and maintenance to the farm machinery & 48 & 50 & 50 \\
\hline 6. Crop insurance & 34 & 36 & 36 \\
\hline 7. Drying / conditioning & 0 & 0 & 0 \\
\hline 8. Interests for capital & 0 & 0 & 0 \\
\hline 9. Other costs (collected by others) & 322 & 330 & 330 \\
\hline Total variable costs & 3098 & 3156 & 3372 \\
\hline 10. Amortization of investing works in land + rent & 41 & 43 & 43 \\
\hline 11. Amortization of farm machinery & 80 & 82 & 82 \\
\hline 12. Interests on fixed capital & 46 & 47 & 47 \\
\hline 13. Crop insurance & 34 & 36 & 36 \\
\hline 14. Storing and preserving agricultural products & 0 & 0 & 0 \\
\hline 15. Employment and Management & 729 & 730 & 744 \\
\hline Total fixed costs & 930 & 938 & 952 \\
\hline Total variable and fixed costs & 4029 & 4094 & 4323 \\
\hline
\end{tabular}


strenghtening, which confers a better lodging REFERENCES

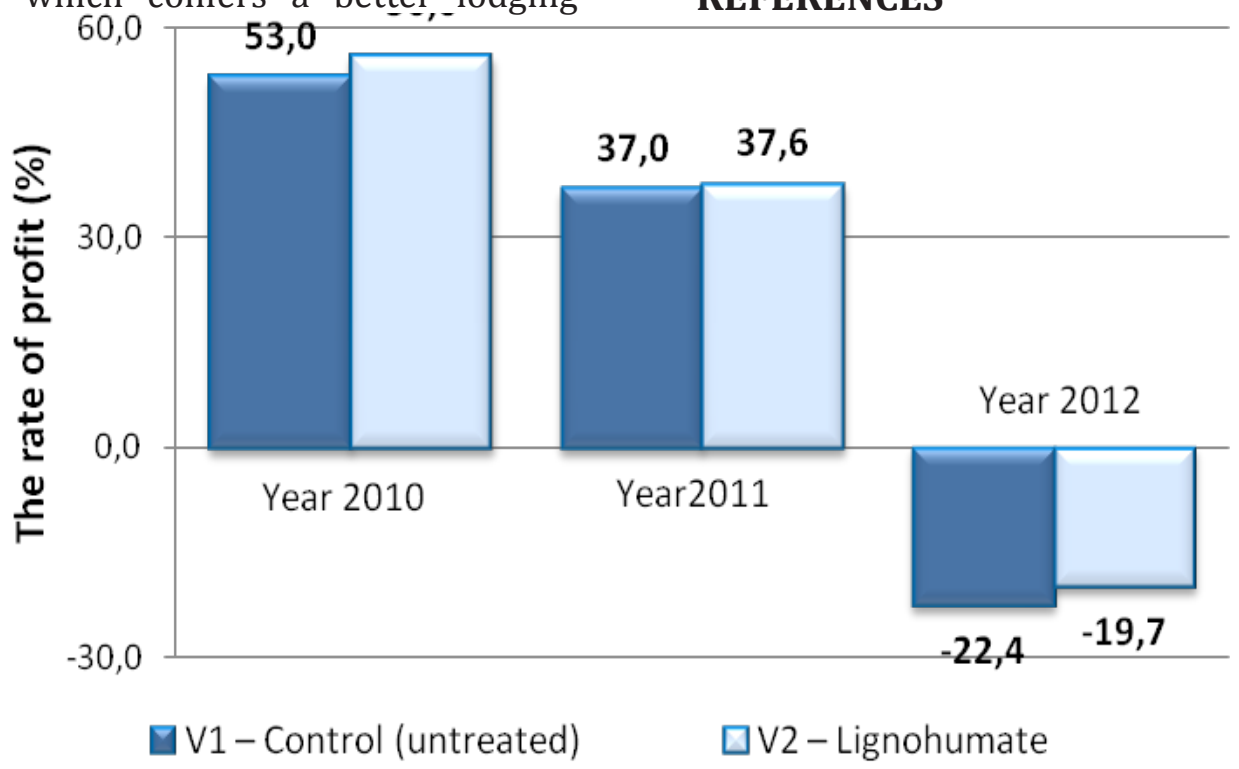

Fig. 5. Economic efficiency analysis on Lignohumate

Tab. 5 The influence of Lignohumat on economic efficiency in soybean crop

\begin{tabular}{ccccccc}
\hline \multirow{2}{*}{ Year } & Variant & $\begin{array}{c}\text { Yield (kg/ } \\
\text { ha) }\end{array}$ & $\begin{array}{c}\text { Total costs } \\
\text { (lei) }\end{array}$ & $\begin{array}{c}\text { Yield value } \\
\text { (lei) }\end{array}$ & $\begin{array}{c}\text { The profit } \\
\text { (\%) }\end{array}$ & $\begin{array}{c}\text { Rate of } \\
\text { profit (\%) }\end{array}$ \\
\hline \multirow{2}{*}{2010} & $\mathrm{~V}_{1}$ Control & 4402 & 4029 & 6163 & 2134 & 53.0 \\
\cline { 2 - 7 } & $\mathrm{V}_{2}$ Lignohumate* & 4536 & 4071 & 6350 & 2280 & 56.0 \\
\hline \multirow{2}{*}{2011} & $\mathrm{~V}_{1}$ Control & 3504 & 4094 & 5606 & 1513 & 37.0 \\
\cline { 2 - 7 } & $\mathrm{V}_{2}$ Lignohumate* & 3558 & 4136 & 5693 & 1557 & 37.6 \\
\hline \multirow{2}{*}{2012} & $\mathrm{~V}_{1}$ Control & 1766 & 4323 & 3355 & -968 & -22.4 \\
\cline { 2 - 7 } & $\mathrm{V}_{2}$ Lignohumate* & 1844 & 4365 & 3504 & -862 & -19.7 \\
\hline \multirow{2}{*}{ Lignohumate treatment -100 g/10 L water/t seeds +60 g/ha /300 L water in the 2-3leaves stage, before and after flowering }
\end{tabular}

resistance.

\section{CONCLUSION}

The humic fertilizer Lignohumate positively influenced the productivity elements, the yield and the profit rate for the soybean crop. Thus, we can conclude that it has prospects to be successfully used by adding it to the classical crop technology.

There are prospects for this humic fertilizer to be tested in other crops, possibly in a nonconventional tillage.

Acknowledgment. This paper was published under the frame of European Social Fund, Human Resources Development Operational Programme 2007-2013, project no. POSDRU/159/1.5/S/ 132765.
1. Axinte M., Mogârzan A, Ungureanu O (2002). Fitotehnie, Lucrări practice Vol I. USAMV Iași.

2. Borlan Z, Hera C, Dornescu D, Kurtinecz P, Rusu M, Buzdugan I, Tănase Gh (1994). Fertilitatea şi fertilizarea solurilor (Compediu de agrochimie), Editura Ceres București. ISBN 973-40-0314-3.

3. Eyheraguibel B, Silvestre J, Morard P, (2008). Effects of humic substances derived from organic waste enhancement on the growth and mineral nutrition of maize. Bioresource Technology, 99, 4206-4212, ISSN 0960-8524.

4. Eladia MPM, Havel J, Patočka J (2005). Humic substances - compounds of still unknown structure: applications in agriculture, industry, environment, and biomedicine. J. Appl. Biomed. 3: 13:24, ISSN 1214-0287.

5. Galeș DC, Jităreanu G (2014). The influence of humic fertilizer on morphological and physiological properties of maize crop, in the conditions of the Moldavian Plateau. Lucrări Ştiințifice - vol. 57, seria Agronomie.

6. Leenheer JA (2002). Analysis of non-humic components of dissolved organic matter. Symposia Papers Presented 
Before the Division of Environmental Chemistry American Chemical Society Orlando, FL April 7-11, vol 42, nr. 1.

7. Oleg G, Rodion P (2010). Efficiency and Application Prospects of Humatized Mineral Fertilizers, 15th Meeting of the International Humic Substances Society Tenerife Canary Islands. June 27- July 2.

8. Stefan M (2008). Biologia microorganismelor rizosferice - aplicații biotehnologice, Ed. Tehnopress Iași, ISBN 973702-597-5, p. 369.
9. Topa D, Jitareanu G, Ailincai C, Raus L (2013). Impactul unor sisteme minime asupra productiei si fertilitatii solului. Ed. Ion Ionescu de la Brad - Iasi, ISBN 978-973147-122-8.

10. ***, 1999. STAS - SR 6123 - Determined Thousand Grain Weight

11. ${ }^{* *}, 1$ 1999. STAS - SR 6123-2 - Determined Hectolitric Weight

12. ***, 1999. STAS - SR 6124-1 - Determined seed moisture 